\title{
DIFFUSE PANBRONCHIOLITIS: AN UNDERDIAGNOSED DISEASE? STUDY OF 4 CASES IN BRAZIL
}

\author{
Rogério Souza, Ronaldo Adib Kairalla, Ubiratan de Paula Santos,
} Teresa Yae Takagaki, Vera Luiza Capelozzi and Carlos Roberto Ribeiro Carvalho

SOUZA R et al. - Diffuse panbronchiolitis: an underdiagnosed disease? Study of 4 cases in Brazil. Rev. Hosp. Clín. Fac. Med. S. Paulo 57(4):167-174, 2002.

BACKGROUND: Diffuse panbronchiolitis is a clinical pathologic condition characterized by chronic inflammation of respiratory bronchioles, with clinical features that position it as a differential diagnosis among the sinopulmonary syndromes.

METHODS AND RESULTS: We present 4 cases (1 Black, 2 Japanese descendants, and 1 Japanese), living in Brazil, in which the diagnosis was made by the clinical and radiological features and confirmed by transbronchial biopsy. The clinical findings included chronic sinusitis, productive cough, rhonchi, and wheezes. The pulmonary function tests showed an obstructive pattern. High resolution computerized tomography showed a diffuse nodular pattern, airway ectasia, and airway wall thickening. The biopsy showed interstitial accumulation of foam cells and lymphoid cells in the walls of respiratory bronchioles: 2 of our cases had bronchus-associated lymphoid tissue hyperplasia. We searched for the HLA Bw54 in all of our patients, but only 1 was positive. A low dose macrolide treatment was introduced, resulting in with clinical and functional improvement. A score that rated the extent of nodules, airway ectasia, mucus plugging, and airway wall thickening was applied on pre- and post-treatment High resolution computerized tomography results, revealing an improvement in tomographic pattern related to that observed in the pulmonary function tests.

CONCLUSION: We conclude that diffuse panbronchiolitis is a systemic disease that is not exclusive to the Asian population, whose clinical and radiological features should be better known by occidental pulmonary physicians.

DESCRIPTORS: Diffuse Panbronchiolitis. Bronchiolitis. Sinopulmonary syndromes. Interstitial lung disease. Bronchiolectasis.

\section{INTRODUCTION}

Diffuse panbronchiolitis (DPB) is a clinical pathologic condition characterized by chronic inflammation of respiratory bronchioles; it was first described in 1969 by Yamanaka et al. ${ }^{1}$. In 1983, a large number of cases were reported, and the clinical features and diagnostic criteria were summarized ${ }^{2}$, introducing DPB as a differential diagnosis among the sinopulmonary syndromes. Although, this disease has primarily been observed in Japan, case reports around the world (in South
America $^{3}$, North America ${ }^{4,5}$, and Europe $^{6}$ ) have been described. In these cases, the disease has occurred in patients either with or without a travel history to the Far East. The paucity of cases outside Japan, in Asian or nonAsian patients, may reflect a genetic/ environmental factor or a misdiagnosis of the disease. In this study, the clinical, radiologic, and pathologic features of 4 cases in people living in Brazil:

From the Pulmonary Division, Hospital das Clínicas, Faculty of Medicine, University of São Paulo.
1 Black, 1 Japanese, and 2 of Japanese descent.

\section{METHODS}

We describe 4 cases presented at our division between 1995 and 1998. To reach the diagnosis of DPB, we used the following diagnostic criteria ${ }^{2,7}$ : a) symptoms of chronic cough, sputum, and dyspnea on exertion; b) physical signs of rales and rhonchi; c) chest radiograph showing diffusely disseminated fine nodular shadows, mainly in the lower 
lung fields with hyperinflation; d) the presence of at least 3 of the following findings in a pulmonary function test: the ratio between forced expiratory volume in 1 second and forced vital capacity (FEV1/FVC) < 70\% (absolute ratio); FVC $<80 \%$ (predicted value); residual volume $>150 \%$ (predicted value); or $\mathrm{PO}_{2}<80 \mathrm{mmHg}$. The summary of the clinical findings for our patients and of the pulmonary function tests can be seen in tables 1 and 2 .

We also searched for the presence of HLA Bw54, rheumatoid factor, and antinuclear antibodies, and we measured the cold-agglutinin titer as the level of immunoglobulin. Sputum specimens from the 4 patients were taken to determine the infection/colonization of the airways. The laboratory findings are described in table 3.

Chest radiographs and high resolution computed tomography (HRCT) were taken. The radiological findings are summarized in table 4 . We used HRCT as a method of treatment follow up, utilizing a score that evaluated the extent of nodular lesions, airway ectasia, and mucus plugging, and the degree of airway ectasia and airway wall thickening ${ }^{8}$. The results of this score can also be seen in table 4 .
Our 4 patients underwent transbronchial biopsy. The histological pattern used as a diagnostic criterion ${ }^{9}$ was the following: diffuse chronic airway inflammation, with the predominant site of the chronic inflammation being the wall of membranous or respiratory bronchioles and the centrilobular regions, interstitial accumulation of foam cells, and lymphoid cells in the wall of respiratory bronchioles and adjacent alveolar ducts and alveoli (described as the DPB unit lesion). Bronchus-associated lymphoid tissue (BALT) hyperplasia was also described as a usual finding in $\mathrm{DPB}^{10}$.

Table 1 - Clinical Features.

\begin{tabular}{|c|c|c|c|c|c|c|c|c|c|}
\hline Case & Age/Sex & Race & Cough & Sputum & Dyspnea & $\begin{array}{l}\text { Chronic Sinusitis } \\
\text { (years of symptoms) }\end{array}$ & $\begin{array}{l}\text { Smoking History } \\
\text { (packs/year) }\end{array}$ & Wheezes & $\begin{array}{l}\text { Crackles } \\
\text { Rhonchi }\end{array}$ \\
\hline 1 & 58/Male & Asian & + & + & + & 25 & $\begin{array}{c}25 \\
\text { (quit } 6 \mathrm{yr} \text { ago) }\end{array}$ & + & + \\
\hline 2 & 63/Male & Asian & + & + & + & 18 & $\begin{array}{c}10 \\
\text { (quit } 36 \mathrm{yr} \text { ago) }\end{array}$ & + & + \\
\hline 3 & 70/Male & Asian & + & + & + & 8 & $\begin{array}{c}21 \\
\text { (quit } 40 \mathrm{yr} \text { ago) }\end{array}$ & + & + \\
\hline 4 & 43/Male & Black & + & + & + & 18 & $\begin{array}{c}\text { no tobacco } \\
\text { history }\end{array}$ & + & + \\
\hline
\end{tabular}

+ present

Table 2 - Parameters of pulmonary function before and after 6 months of low dose macrolide treatment.

\begin{tabular}{|c|c|c|c|c|c|c|c|}
\hline & Case & $\mathrm{FVC}$ & FEV1 & FEV1/FVC (\%) & $\begin{array}{c}\text { FEF 25-75 } \\
\text { (predicted value \%) }\end{array}$ & Dlco $(\%)$ & $\mathrm{SatO}_{2}$ at room air breathing $(\%)$ \\
\hline \multirow[t]{2}{*}{1} & Before & $\begin{array}{c}2.06 \\
(53 \%)\end{array}$ & $\begin{array}{c}1.41 \\
(49 \%)\end{array}$ & 68 & 22 & 61 & 90 \\
\hline & After & $\begin{array}{c}2.23 \\
(57 \%)\end{array}$ & $\begin{array}{l}1.40 \\
(48 \%)\end{array}$ & 63 & 40 & 75 & 91 \\
\hline \multirow[t]{2}{*}{2} & Before & $\begin{array}{c}1.58 \\
(75 \%)\end{array}$ & $\begin{array}{c}0.78 \\
(46 \%)\end{array}$ & 50 & 25 & 37 & 71 \\
\hline & After & $\begin{array}{c}2.23 \\
(107 \%)\end{array}$ & $\begin{array}{c}1.26 \\
(74 \%)\end{array}$ & 57 & 24 & 76 & 90 \\
\hline \multirow[t]{2}{*}{3} & Before & $\begin{array}{c}3.03 \\
(88 \%)\end{array}$ & $\begin{array}{c}1.55 \\
(57 \%)\end{array}$ & 51 & 20 & $\begin{array}{c}\text { Not } \\
\text { determined }\end{array}$ & 86 \\
\hline & After & $\begin{array}{c}3.26 \\
(95 \%)\end{array}$ & $\begin{array}{c}2.09 \\
(77 \%)\end{array}$ & 64 & 37 & 96 & 91 \\
\hline \multirow[t]{2}{*}{4} & Before & $\begin{array}{l}1.89 \\
(60 \%)\end{array}$ & $\begin{array}{c}0.93 \\
(35 \%)\end{array}$ & 59 & 13 & 61 & 90 \\
\hline & After & $\begin{array}{c}1.97 \\
(63 \%)\end{array}$ & $\begin{array}{c}1.10 \\
(41 \%)\end{array}$ & 66 & 21 & 59 & 94 \\
\hline
\end{tabular}

$\mathrm{FVC}=$ Forced Inspiratory Capacity

FEV1 = Forced Expiratory Volume at 1st second

FEF25 75 = Forced Expiratory Flow at middle FVC

DLco $=$ Carbon Monoxide Diffusing Capacity 
Table 3 - Laboratory Results.

\begin{tabular}{ccccccc}
\hline Case & HLA Bw54 & Cold-Agglutinin titer & ANA & RF & Immunoglobulin & Sputum Culture \\
\hline 1 & Negative & negative & $1: 40$ & 258 & IgG $=1620 \mathrm{mg} / \mathrm{dl}$ & $\begin{array}{c}\text { Pseudomonas } \\
\text { aeruginosa }\end{array}$ \\
2 & Positive & negative & negative & negative & IgA $=415 \mathrm{mg} / \mathrm{dl}$ & $\begin{array}{c}\text { Stenotrophomonas } \\
\text { maltophilia }\end{array}$ \\
3 & Negative & negative & $1: 40$ & negative & IgG $=1680 \mathrm{mg} / \mathrm{dl}$ & Pseudomonas sp \\
4 & Negative & negative & negative & negative & IgG $=1640 \mathrm{mg} / \mathrm{dl}$ & Staphylococcus aureus \\
\hline $\begin{array}{l}\text { ANA }=\text { antinuclear antibodies } \\
\text { RF }=\text { rheumatoid factor }\end{array}$ & & & & & &
\end{tabular}

Table 4 - Radiograph Findings.

\begin{tabular}{|c|c|c|c|}
\hline Case & Chest X-ray & HRCT & $\begin{array}{c}\text { CT Score } \\
\text { (pre/post-treatment) }\end{array}$ \\
\hline 1 & $\begin{array}{l}\text { Bilateral nodular infiltrate } \\
\text { Airway wall thickening } \\
\text { Bronchiectasis }\end{array}$ & $\begin{array}{l}\text { Large, medium and small } \\
\text { size bronchi wall thickening } \\
\text { Diffuse bronchiolectasis }\end{array}$ & $12 / 12$ \\
\hline 2 & $\begin{array}{l}\text { Bilateral nodular infiltrate } \\
\text { Airway wall thickening } \\
\text { Hyperinflation }\end{array}$ & $\begin{array}{l}\text { Small airway wall thickening } \\
\text { Mild bronchiolectasis }\end{array}$ & $10 / 07$ \\
\hline 3 & $\begin{array}{c}\text { Bilateral reticulonodular infiltrate } \\
\text { Hyperinflation }\end{array}$ & $\begin{array}{l}\text { Small airway wall thickening } \\
\text { Mild bronchiolectasis }\end{array}$ & $13 / 05$ \\
\hline 4 & $\begin{array}{l}\text { Bilateral reticulonodular infiltrate } \\
\text { Hyperinflation }\end{array}$ & $\begin{array}{l}\text { Medium and small airway wall thickening } \\
\text { Mild bronchiolectasis }\end{array}$ & $11 / 07$ \\
\hline
\end{tabular}

HRCT = High Resolution Computed Tomography

Our 4 patients fulfilled this pathologic criterion, including the presence of BALT hyperplasia seen in patients 2 and 3. A sample of the histopathologic findings can be seen in figure 1.

\section{CASE 1}

A 58-year-old male, born in Japan, and living in Brazil for 30 years, and traveling to Japan annually for the last 10 years. He had a 25 pack/year history of tobacco use but had discontinued 6 years ago. He had experienced chronic sinusitis since the age of 33 . About 15 years ago, he started experiencing dyspnea, dry cough, and wheezing in episodes that lasted about 3 to 4 days. Since 1993, the cough had been productive, and he had a worsening of the dyspnea and wheezing.

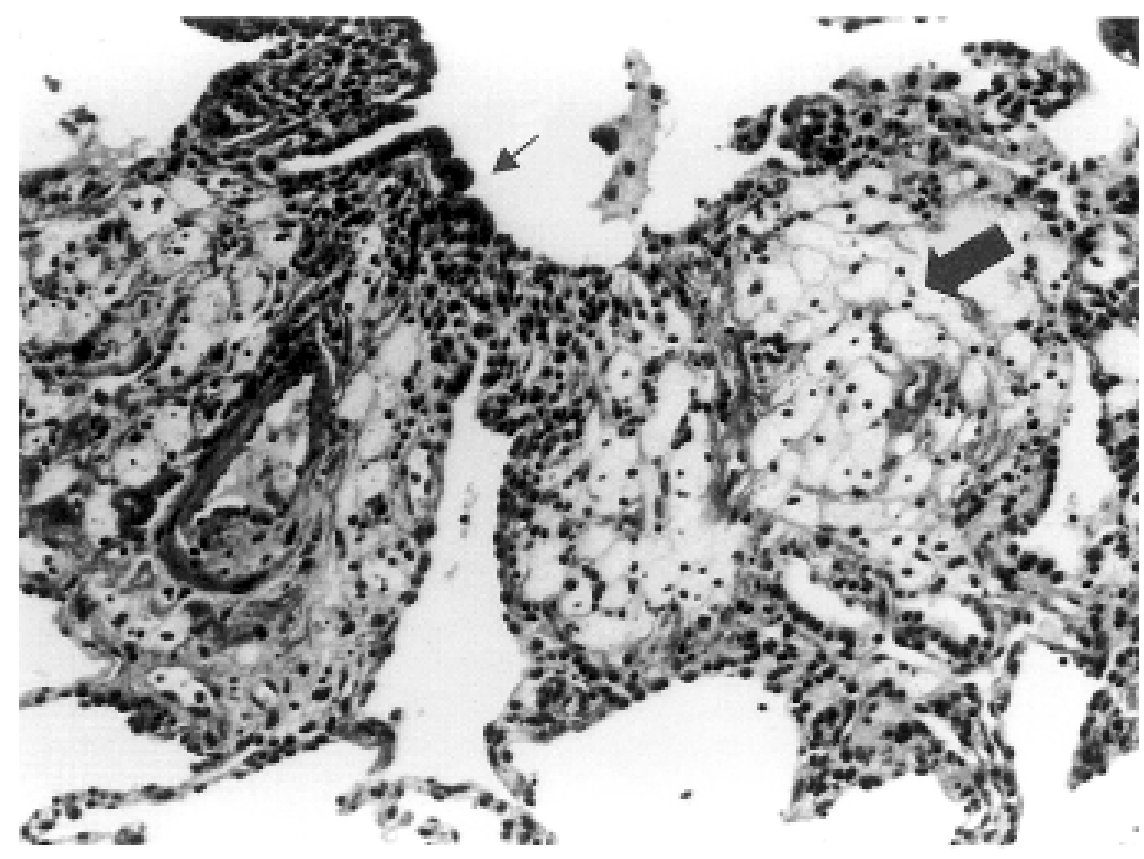

Figure 1 - Histopathologic picture of transbronchial biopsy of patient 1 showing branched lymphocytes and foam cells interstitial accumulation (large arrow); BALT hyperplasia (small arrow). (hematoxylin and eosin x 100). 
Physical examination revealed diffuse expiratory wheezes and inspiratory crackles mainly in the basal portions of the lungs. Sinus films revealed bilateral maxillary disease. The chest radiograph and HRCT are described in Table 4. Pulmonary function tests showed a marked flow limitation. The patient started a low-dose erythromycin treatment that resulted in clinical improvement.

\section{CASE 2}

A 63-year-old male, born in Brazil; Japanese parents. He had a 10 pack/ year history of tobacco use but stopped 36 years ago. He had no history of traveling to the Far East. He had an 18-year history of type 2 diabetes mellitus and chronic sinusitis. Ten years ago, he started experiencing dry cough and mild dyspnea on exertion. The symptoms progressively worsened, presenting with sputum, wheezing, and dyspnea after minor effort. At the physical examination, he presented with inspiratory and expiratory crackles and wheezes diffusely in both lungs. The chest radiograph and HRCT are described in table 4. The pulmonary function test revealed an obstructive pattern with signs of hyperinflation. The blood gas analysis showed hypoxemia. The search for HLA Bw54 yielded positive results. Treatment with low-dose erythromycin has been implemented, with clinical, functional, and radiological improvement.

\section{CASE 3}

A 70-year-old male, born in Brazil, Japanese parents, had no history of traveling to the Far East and a tobacco use history of 21 pack/year, discontinued 40 years ago. He has experienced chronic sinusitis since the age of 60 . About 6 years ago, he started experiencing mild dyspnea at exertion and productive cough, which developed in crisis always with wheezing. He had a progressive worsening of the symptoms, experiencing dyspnea with minimal exertion and constant wheezing. At physical examination, he presented with wheezes and rhonchi all over the lungs. The radiological features are described in table 4. High resolution CT is shown in figure 2 . The patient started a low-dose clarithromycin treatment resulting in clinical and functional improvement and a significant change in the radiograph pattern after 6 months of treatment.

\section{CASE 4}

A 43-year-old black male, born in Brazil, with no tobacco use history and chronic sinusitis since the age of 25. Twelve years ago, he started experiencing productive cough and dyspnea at exertion, sometimes with wheezing complaints. Treatment for chronic bronchitis was tried with little success. There was a progressive worsening of the symptoms. At presentation, he had dyspnea with minimal exertion, and the wheezing was present more frequently. At physical examination, he presented with wheezes and rhonchi all over the lungs. The chest radiograph and high resolution $\mathrm{CT}$ are described in table 4. After a low-dose erythromycin treatment, the patient presented clinical and functional improvement.

\section{DISCUSSION}

The diagnosis of DPB is based on clinical, functional, radiological, and histological criteria. None of these is a sufficient criterion by itself, since the isolated finding at any of these criteria is nonspecific and could lead to a misdiagnosis, such as chronic bronchitis, and therefore to an inadequate treatment.

The histological pattern described for the diagnostic criterion ${ }^{9}$ found in our 4 patients should not be analyzed by itself, since other conditions and diseases, such as cystic fibrosis, bronchiectasis and constrictive bronchiolitis obliterans, could present the DPB unit lesion ${ }^{11}$. Therefore, the clinicopathological correlation is the key for the correct diagnosis of DPB.

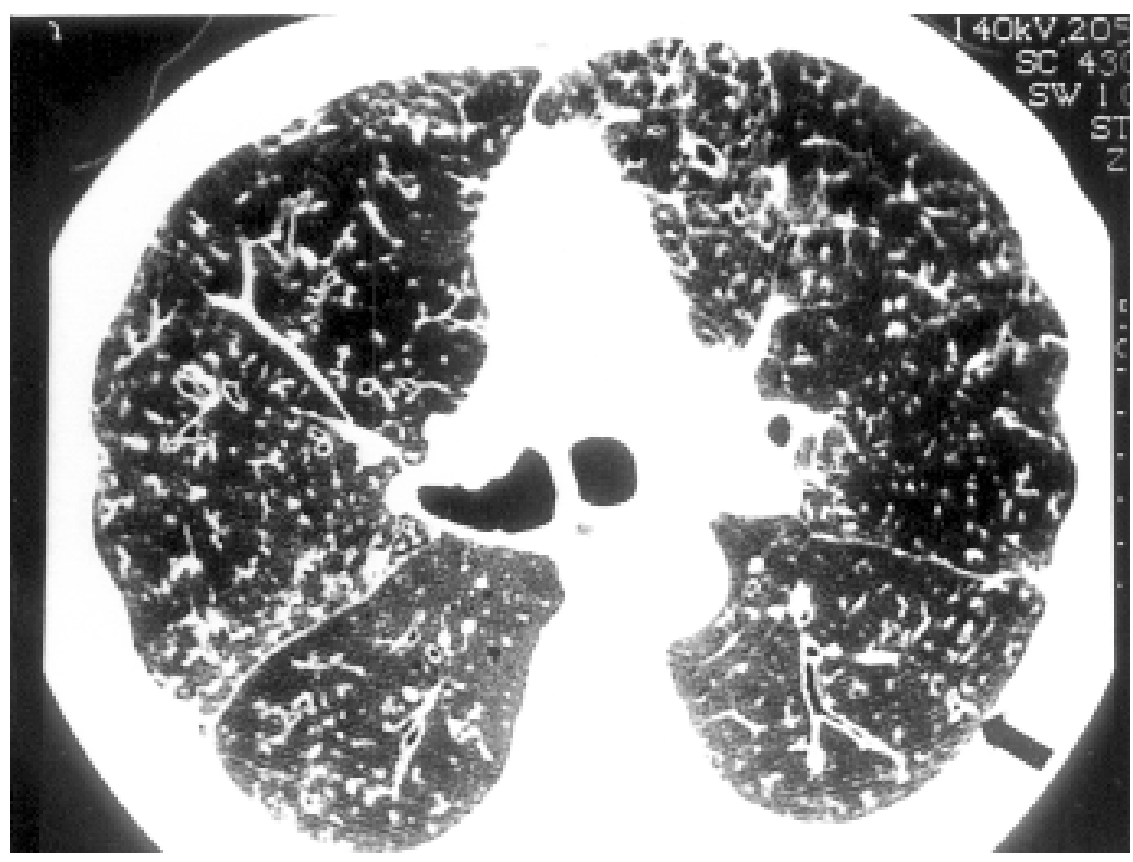

Figure 2 - Thoracic high resolution CT patient 3 showing diffuse small airway wall thickness nodular infiltrate and bronchiolectasis (small arrow). 
Other findings that could help with the diagnosis of this condition are chronic paranasal sinusitis ${ }^{2,7}$ and a persistent elevation of cold agglutinin ${ }^{12}$. The symptoms of chronic sinusitis are present in more than $75 \%$ of the patients and often precede the lower respiratory tract symptoms by years ${ }^{7}$. Cold agglutinin titer elevation is nonspecific; in DPB it is usually polyclonal and rises up to 64 times the normal level. This kind of elevation can also be seen in infections, such as those caused by Mycoplasma. However, in DPB patients, the serological tests for Mycoplasma are usually negative. Although useful, a normal cold agglutinin level does not exclude $\mathrm{DPB}$, as observed in our patients ${ }^{13}$.

The sputum cultures usually are positive and reveal possible infection or colonization of the airways with Haemophilus influenza, and less commonly with Streptococcus pneumoniae, Klebsiella pneumoniae, or Staphylococcus aureus ${ }^{2,7}$. In a later stage, these agents are replaced by Pseudomonas aeruginosa or other Pseudomonas species that could represent a sign of an advanced stage of the disease ${ }^{13}$. Two of our patients presented with $\mathrm{Pseu}$ domonas at sputum culture. One of them (case 1), who presented with Pseudomonas aeruginosa, had used a large number of antibiotics before the diagnosis and had only clinical improvement, with no significant pulmonary function or radiological change after macrolide treatment. This led us to wonder whether the presence of Pseudomonas is a sign of an advanced stage or is rather a sign of a chronic phase after a misdiagnosis and excessive use of antibiotics.

The pulmonary function tests (PFT) often reveal airflow limitation with reduced diffusing capacity and hypoxemia ${ }^{2}$, as was observed in our patients. After at least 6 months of treatment, all of them had an improvement on the PFT. Two cases showed a marked increase in the FEV1, in the $\mathrm{FEF}_{25-75 \%}$, and in the arterial hemoglobin oxygen saturation. Case 2 showed also an increase in DLCO (more than 2-fold). Case 1 showed only a mild improvement, which could be seen as an increased $\mathrm{FEF}_{25-75 \%}$ and DLCO. These findings reflect the clinical improvement of these patients after the correct diagnosis and treatment. This improvement was reported as a reduction in the number of infections, reduction in the amount of sputum, and a subjective improvement in the capacity for physical exertion that made possible the return of the patients to their normal activities.

The major HRCT findings included small rounded areas and branched linear areas of attenuation, thickened and dilated walls of bronchioles and bronchi, and disparities in lung density between the inner and the outer lung zones as a result of air trapping. These areas of attenuation corresponded to nodular lesions that are found histologically to be the chronic inflammatory and fibrotic lesions in and around the membranous and respiratory bronchioles and adjacent alveolar ducts and alveoli ${ }^{9}, 14$. These alterations can be seen in the sample presented as the figure 2 .

In an interesting study, a CT score system was proposed that showed good correlation with the pulmonary function test changes after low-dose, longterm erythromycin treatment ${ }^{8}$. We used this score system as a complementary evaluation of the post-treatment improvement. We found that 3 of our patients showed a functional improvement that was correlated with the evolution of the HRCT lesions. The other patient, even with a significant reduction in the symptoms, had only a mild functional improvement and presented no changes in the radiological pattern evaluated by the CT score.

The findings at lung biopsy and in the analysis of bronchoalveolar lavage fluid $^{15-17}$ do not clarify the real mechanism of treatment with low dose, long- term macrolide. Many changes have been reported as a consequence of erythromycin treatment, such as a decrease in the polymorphonuclear leukocyte-direct migration ${ }^{18}$, suppression of hypersecretion ${ }^{19}$, and a decreased percentage of activated $\mathrm{T}$ cells with the expression of HLA-DR in the peripheral blood of DPB patients ${ }^{20}$.

We do know that the antibacterial action of the erythromycin against the usual isolated organisms from cultures of sputum of DPB patients $(H$. influenza and $P$. aeruginosa) could not be considered as an important mechanism, since the concentration of erythromycin in sputum and serum (with the usual dose of $600 \mathrm{mg}$ daily) are very far below the minimum inhibitory concentration required for these organisms ${ }^{21}$. In spite of this, the use of low dose, long-term macrolide treatment figures as the one with large number of studies showing clinical, functional, and radiological improvement ${ }^{8,16,22-24}$, as well as reduction in the mortality rate ${ }^{25}$.

The etiology and mechanism of injury in DPB are unknown. The presence of certain antigens (i.e. HLA Bw54) and the finding of familial cases suggest a genetic background to this disease, which could explain its increased prevalence in Far East populations and its rarity in occidental populations. The HLA Bw54 antigen is present at a high frequency in the Japanese population (11\% in normal subjects and $63 \%$ in DPB patients) ${ }^{26}$. Only 1 of our patients was positive for the HLA Bw54 antigen, despite 3 of them being of Japanese descent. Thus, we believe that the HLA Bw54 antigen should not be used as a screening test, but it should be used as another diagnostic test and as an attempt to clarify the physiopathologic mechanism of this disease.

There is only one other description of DPB in a black patient ${ }^{27}$; and only few cases in Caucasians ${ }^{3-6}$. This finding could be a reflection of a different 
mechanism, a different trigger, or a difficulty in diagnosis by the Western physicians. Whether other alleles could play a role in these populations is yet to be studied ${ }^{28}$.

The opinions regarding association of DPB with environmental factors are changing. Initially the reports outside the Far East were interpreted to suggest that the travel history should be a major factor for the diagnosis of DPB $^{5}$. However, other cases outside the Far East and without travel history in the Far East have been reported 3,4,6, and this was also observed in our pa- tients 2,3 , and 4 .

The finding of an association between DPB and rheumatoid arthritis ${ }^{29,30}$ or even the recurrence of DPB after bilateral lung transplantation ${ }^{27}$ suggests that DPB could be part of a systemic disease. But the physiopathologic mechanism that could explain this kind of behavior has not been clarified yet.

Until now, the final presentation of DPB was thought to be a result of influence of each one of the factors mentioned above: genetic, environmental, infectious, and systemic immune re- sponse with an unknown trigger.

We believe that, in part, the low prevalence of the DPB in the Occidental populations could also be a result of the lack of knowledge about this condition, leading to misdiagnosis. HRCT can be used as an important method for diagnosis of suspicious cases and treatment follow-up for DPB patients. Its characteristic, but not diagnostic, pattern should be better known by Occidental pulmonary physicians as a differential diagnosis among the sinopulmonary syndromes.
SOUZA R e col. - Panbronquiolite difusa: uma doença subdiagnosticada? Estudo de quatro casos no Brasil. Rev. Hosp. Clín. Fac. Med. S. Paulo 57(4):167-174, 2002.

INTRODUÇÃO: A Panbronquiolite Difusa é uma entidade clínico-patológica caracterizada pela inflamação crônica dos bronquíolos respiratórios e que, clinicamente, apresenta-se como diagnóstico diferencial das síndromes sino-pulmonares.
MÉTODOS E RESULTADOS: Apresentamos 4 casos (um negro, dois descendentes de japoneses e um japonês), que moram no Brasil, nos quais a suspeita diagnóstica se baseou nos aspectos clínicos e radiológicos e foi confirmada através da biópsia transbrônquica. As principais características clínicas eram sinusite crônica, tosse produtiva, além da presença de roncos e sibilos. Os testes de função pulmonar evidenciaram um padrão obstrutivo. A tomografia de tórax de alta resolução demonstrou um padrão nodular difuso, além de ectasia e espessamento das paredes das vias aéreas. O exame histológico evidenciou acúmulo intersticial de macrófagos xantomatosos e infiltração de linfócitos na região dos bronquíolos respiratórios, sendo que 2 de nossos casos ainda apresentaram hiperplasia de tecido linfocitário associado aos brônquios. Investigamos a presença do HLA Bw54 nos quatro casos, sendo apenas um positivo. Após o diagnós- 
tico, instituiu-se o tratamento com macrolídeos em dose baixa, tendo como resultado melhora clínica e funcional. Um escore que avalia a extensão do padrão nodular, a ectasia e o espessamento das vias aéreas e ainda o grau de impactação mucóide visíveis à tomografia foi utilizado pré e pós tratamento evidenciando uma melhora compatível com a observada à função pulmonar.

CONCLUSÃO: Concluímos que a Panbronquiolite Difusa é uma doença sistêmica, não exclusiva da população oriental, cujas características clínicas e radiológicas devem ser melhor conhecidas pelos médicos ocidentais.

DESCRITORES: Panbronquiolite Difusa. Bronquiolite. Síndrome SinoPulmonar. Doença Intersticial Pulmonar. Bronquiolectasia.

\section{REFERENCES}

1. YAMANAKA A, SAIKI $S$ \& TAMURA $S$ - The problems of chronic obstructive pulmonary disease: Especially concerning diffuse panbronchiolitis. Naika 1969; 23: 442-451.

2. HOMMA H, YAMANAKA A \& TANIMOTO S - Diffuse panbronchiolitis. A disease of the transitional zone of the lung. Chest 1983; 83: 63-69.

3. MARTINEZ J, PEREIRA L, GUIMARÃes $S$ et al. - Diffuse panbronchiolitis in Brazil. Report of two cases. Am J Respir Crit Care Med 1997; 155: A326.

4. FITZGERALD J, KING T, LYNCH D et al. -Diffuse panbronchiolitis in the United States. Am J Respir Crit Care Med 1996; 154: 497-503.

5. HOMER R, KHOO L \& SMITH G -Diffuse panbronchiolitis in a Hispanic man with travel history to Japan. Chest 1995; 107: 1176-1178.

6. POletti V, PATElli M, POLETti G et al. - Diffuse panbronchiolitis observed in an Italian male. Sarcoidosis 1992; 9: 67-69.

7. HOMMA H - Definition of diffuse panbronchiolitis. Jpn Intern Med 1976; 65: 649-659.

8. ICHIKAWA Y, HOTTA M, SUMITA S et al. - Reversible airway lesions in diffuse panbronchiolitis (detection by high resolution computed tomography). Chest 1995; 107: 120-125.

9. KITAICHI M -Pathology of diffuse panbronchiolitis from the viewpoint of differential diagnosis. Sarcoidosis 1988; 5: 741746.

10.SATO A, CHIDA K, IWATA M et al. - Study of bronchus-associated lymphoid tissue in patients with diffuse panbronchiolitis. Am Rev Respir Dis 1992; 146: 473-478.

11.IWATA M, COLBY T \& KITAICHI M - Diffuse panbronchiolitis: diagnosis and distinction from various pulmonary diseases with centrilobular interstitial foam cell accumulations. Hum Pathol 1994; 25: 357-362.
12.TAKIZAWA H, TADOKORO K \& MIYOSHI Y - Serological characterization of cold agglutinin in patients with diffuse panbronchiolitis. Jpn J Thorac Dis 1986; 24: 257.

13.SUGIYAMA Y - Diffuse panbronchiolitis. Clin Chest Med 1993; 14: $765-771$.

14.NISHIMURA K, KITAICHI M, IZUMI T et al. - Diffuse panbronchiolitis: correlation of high resolution CT and pathologic findings. Radiology 1992; 184: 779-785.

15.KADOTA J, SAKITO S, KOHNO S et al. - A mechanism of erythromycin treatment in patients with diffuse panbronchiolitis. Am Rev Respir Dis 1993; 148: 744-751.

16.KADOTA J, SAKITO O, KOHNO S et al. -Roxithromycin treatment in patients with chronic lower respiratory tract diseases - its clinical efficacy and effect on cytokine. J Jpn Assoc Infect Dis $1994 ;$ 68: $27-33$.

17.MUKAE H, KADOTA J, KOHNO S et al. - Increase in activated CD8+ cells in bronchoalveolar lavage fluid in patients with diffuse panbronchiolitis. Am J Respir Crit Care Med 1995; 152: 613-618.

18.NELSON S, SUMMER W \& TERRY P - Erythromycin-induced suppression of pulmonary antibacterial defenses. A potential mechanism of superinfection in the lung. Am Rev Respir Dis 1987; 136: 1207-1212.

19.GOSWAMI S, KIVITY S \& MAROM Z - Erythromycin inhibits respiratory glycoconjugate secretion from human airways in vitro. Am Rev Respir Dis 1990; 141: 72-78.

20.SUGIYAMA Y, SUGAMA Y \& TAKEUCHI K - Analysis of peripheral lymphocyte subsets and changes due to erythromycin therapy in patients with diffuse panbronchiolitis. Jpn J Thorac Dis 1990; 28: 1574-1580.

21.NAGAI H, SHISHIDO H \& YONEDA R - Long-term low-dose administration of erythromycin to patients with diffuse panbronchiolitis. Respiration 1991; 58: 145-149. 
22.KUDOH S, UETAKE T \& HAGIWARA K - Clinical effect of lowdose long-term erythromycin chemotherapy on diffuse panbronchiolitis. Jpn J Thorac Dis 1987; 25: 632-642.

23.AKIRA M, HIGASHIHARA T, SAKATANI M et al. - Diffuse panbronchiolitis: follow-up CT examination. Radiology 1993; 189: $559-562$.

24.ICHIKAWA Y, NINOMIYA H, KOGA H et al. - Erythromycin reduces neutrophils and neutrophil-derived elastolytic-like activity in the lower respiratory tract of bronchiolitis patients. Am Rev Respir Dis 1992; 146: 196-203.

25.KUDOH S, AZUMA A, YAMAMOTO M et al. - Improvement of survival in patients with diffuse panbronchiolitis treated with low-dose erythromycin. Am J Respir Crit Care Med 1998; 157: $1829-1832$.

26.SUGIYAMA Y, KUDOH S \& MAEDA H - Analysis of HLA antigens in patients with diffuse panbronchiolitis. Am Rev Respir Dis 1990; 141: 1459-1462.
27.BAZ M, KUSSIN P, VAN TRIGT P et al. - Recurrence of diffuse panbronchiolitis after lung transplantation. Am J Respir Crit Care Med 1995; 151: 895-898.

28.PARK M, KIM Y, YOON H et al. - Association of HLA class I antigens with diffuse panbronchiolitis in Korean patients. Am J Respir Crit Care Med 1999; 159: 526-529.

29.HOMMA S, KAWABATA M, KISHI K et al. - Diffuse panbronchiolitis in rheumatoid arthritis. Eur Respir J 1998; 12: $444-45$.

30.HAYAKAWA H, SATO A, IMOKAWA $S$ et al. - Diffuse panbronchiolitis and rheumatoid arthritis-associated bronchiolar disease: similarities and differences. Intern Med 1998; 37: 504508.

Received for publication on September 28, 2001 